

\title{
Perception of Management on Outcomes of Human Resource Information System (HRIS)
}

\author{
Md. Abdullah Al Mamun', Md. Shamimul Islam²
}

\begin{abstract}
Human Resource Management is getting focused day by day for ensuring and sustaining organizational success. HRIS (Human Resource Information System) is a prevailing HR tool coupled with contemporary innovation of information system. HRIS is defined as the information system to collect, store, process and retrieve HR information to seamlessly help organization achieve strategic objectives. For installation of HRIS, commitment, decision and action of management are inevitable. This study aims at unveiling implicit perception of management regarding performance of HRIS towards organizational objectives in three perspectives such as "Operational Efficiency (OE)", "Managerial Effectiveness (ME)" and "Strategic Finesse (SF)". 54\% and 57\% respondents respectively agree that HRIS enhances OE and ensures ME. On the other hand, 70\% respondents underline HRIS as SF. However, the hypothesis results showed that management perception toward HRIS performance is independent of experience, gender and education of managerial people but associated with organizational origin either Bangladeshi or foreign. Thus it is concluded that foreign companies are advanced to adopt contemporary tools whereas Bangladeshi firms are averse or endeavor to assimilate laggardly. The findings open the door for future research why Bangladeshi firms respond at late.
\end{abstract}

Keywords: HRM, HRIS information system, Perception.

Available Online: 18-03-2016

This is an open access article under Creative Commons Attribution 4.0 License, 2016.

\section{$1.0 \quad$ INTRODUCTION}

Bangladesh is emerging as a friendly country to adopt and adapt trending technology. Firms are more likely than ever before to invest in competition neutralizing information and technological systems. As a mean of achieving efficiency and minimizing cost of managing human resources, HRIS is getting popularity among practioners in Bangladesh.

${ }^{1}$ Assistant professor, Department of Management, School of Business, Bangladesh University of Business and Technology (BUBT)

${ }^{2}$ Corresponding author, Senior Lecturer, Faculty of Business, ASA University Bangladesh, E-mail: shamimul@asaub.edu.bd 
Information fetches greater opportunities and ensures credible decision of management. Management without pertinent and holistic information risks investment profusely. Firms invest in information systems for the business objectives such as achieving operational excellence (productivity, efficiency, agility), developing new products and services, attaining customer intimacy and service, improving decision making, achieving competitive advantage and ensuring survival (Laudon \& Laudon, 2009). Among multifarious information, human resource information is the key to organizational success. HR information lets management know from HR recruitment to retirement. Thus HRIS here justifies as enabling system to process and measure HR information. As Peter Drucker said, "What gets measured gets managed"

In its simplest form, HRIS is a service provided to an organization in the form of information (Tannenbaum, 1990) to acquire, store, manipulate, analyze, retrieve and distribute those pertinent information about an organization's human resources ( Beadles, Lowery \& Johns, 2010). Though HRIS was initially limited as caretaker of employees Tevavichulada (1997) but includes too many irons in the fire like manpower planning, manpower demand and supply forecasting, job descriptions for both jobs and applicants, recruitment and selection, training and development, negotiations, grievance management etc (Kovach and Cathcart 1999) The advocates of HRIS posit that right information at right time to right people regarding $\mathrm{HR}$ ensures proper utilization of HR toward sustainable competitive advantage of a firm. The potential advantages of HRIS are faster information processing, greater information accuracy, improved planning and program development, and enhanced employee communications (Overman, 1992). Some wrote that HRIS would contribute to reduce HR cost by automating information and lowering the need of large number of HR employees. Some other authors view that HRIS has both administrative and strategic usages resulting ultimately to increase organizational value. But firms are intuitively averse to adopt HRIS because of degree of complexity about the measurability of HRIS outcomes. Mayfield \& et el (2003) postulated that to measure precisely the return on investment and specific improvements in productivity within the HR departments is difficult.

Top management plays key role in installing any company-wide system. In that way, perception of top management underscores as success factor. Roda and Nabeth (2008) opined that what we perceive impacts on what we pay attention to. Many studies concluded that large-scale technology projects failed due to managerial and not technical reasons. Kovach and Cathcart (1999) affirmed that a lack of funds and support of top management are the stumbling blocks in achieving the full potential of HRIS. Beckers and Bsat (2002) avowed that the main obstruction in the implementation of a HRIS is the sky-scraping cost of setting up and maintaining a HRIS. Thus, success of HRIS largely counts on commitments, decisions and actions of top management. This study aims at testing hypothesis about managerial perceptions upon HRIS initiation, installation and maintenance.

\subsection{LITERATURE REVIEW}

Human resource is an extremely valuable resource and is the ultimate source of core competitive advantage (Wei \& Feng, 2013). HRIS ensures efficient outcomes of HR. HRIS is viewed as HR enabling tool to create and disseminate pertinent HR information, which align to strategic direction of an organization. Shaikh (2012) developed three models in his research paper for HRIS designing namely basic HRIS design model, HRIS hexagonal and HRIS phase's model. In a study, Shiri (2012) found that HRIS produces more effective and faster outcomes, has brought about an improvement in the overall HR functions and has assisted in aligning HR practices with the organizational strategy, identifying improvement areas and keeping ahead of current practices thereby enhancing the efficiency of the HR function. Under strategic perspective, Lawler and Mohrman (2003) showed that an integrated HRIS would contribute to avail HR as strategic partner in the strategic management process. But, performance with the HRIS is influenced by system quality; information quality and perceived ease of use (Bal, Bozkurt \& Ertemsir, 2012).

Though top management roots under HRIS, there is still dearth of literature how top management perceives about HRIS usefulness. According to Michal Armstrong (2008) the most significant feature of 
HRM is the importance attached to strategic integration, which flows from top management's vision and leadership, and which requires the full commitment of people to it. To succeed HRM, HRIS plays vital role. And commitment of top management is the key to the HRIS's success. A survey report (Johnson et al, 2001) reported that overall IS project success rate increased from $16 \%$ in 1994 to $28 \%$ in 2000 and attributed five as success factors such as executive support, user involvement, experienced project manager, clear business objectives and minimized scope. In another more recent study, Stone and Davis (2009) observed that lack of leadership, poor plan and communication are the major stumbles of encountering low user acceptance. Teo et al (2007) positioned that top management support is emerged as important variable among others in differentiating between adopters and non-adopters of HRIS. Sometimes, management callously ignores HRIS benefits due to lack of knowledge. Siriwardene \& Dharmasiri (2010) concluded that management's lack of HR knowledge and of the potential benefits of HRIS to the business could also have a negative impact upon HRIS initiation and implementation. (pp-19). Troshani \& et al (2011) also observed that management commitment and human capability in addition to environmental factors can have a deep impact on the success of HRIS adoption by creating urgency in adoption intention. In most instances, however, HRIS is being underutilized by organizations and research has shown that most organizations appear to resort to technology merely to automate routine administrative tasks. Beadles II, Lowery \& Johns (2005) found that HRIS has not yet accomplished this or reached its full potential in the HR environment. In their study, they found that whilst directors overall are satisfied with the system, they have not yet realized the benefits beyond its effect on information and information sharing as the full capabilities of the system were being underutilized. Thus, this study endeavors to test hypothesis regarding perception of top management and HRIS adoption; the variability of management perception toward HRIS in terms of age, gender, seniority, position and education.

Based on the literature review, this study presents following hypothesis.

H1: Management perceptions about HRIS outcome show difference according to gender.

$\mathrm{H} 2$ : Management perceptions about HRIS outcome show difference according to experience.

H3: Management perceptions about HRIS outcome show difference according to educational level.

H4: Management perceptions about HRIS outcome show difference according to company origin.

\subsection{PROPOSED RESEARCH MODEL}

Adoption of HRIS as enabling system is resulted from initiative and support of top management. But HRIS may remain as elusive term to top management despite its usefulness in terms of strategic and operative perspective.



The proposed research model of this study is to assess managerial perception based on HRIS outcomes in three broad perspectives such as "Operational Efficiency", "Managerial Effectiveness" and "Strategic 
Finesse". This study strives to know the relationship functionality of HRIS as outcomes upon organizational performance and background of managerial people.

\subsection{METHODOLOGY}

\subsection{SAMPLING DESIGN}

This study targets the firms both manufacturing and service as population in the capital, Dhaka. The reason behind the confinement is that the business of Bangladesh is mainly Dhaka-based either building plant around Dhaka or running head office in Dhaka, where HR functions are maintained. Regarding sample, the following issues are worth noting-

Target Population
Sampling Element
Extent
Time
Sampling frame
Sampling Techniques
Sample size determination
Sample size (Questionnaire administered)
Sample size (Valid)

Both manufacturing and service organization with employees or workers $>200$

Management (Director, Chairman, CEO \& Manager)

Dhaka, the capital of Bangladesh

May, 2014

Directory (BBS, BB, ICB, $\mathrm{FBBCl}$, NBR, $\mathrm{DMCCl}$ )

Simple Random Probability Sampling

Proportions (calculated below)

246

201 (turn out rate $81 \%$ )

\subsection{SAMPLE SIZE DETERMINATION}

A pilot survey among 20 firms was conducted to estimate population proportion. 16 out of 20 firms positively answered that they have at least some degree of information system to manage human resources of the organization. We determine our sample size using standard model: $n=z^{2} p q / d^{2}$. Where, $\mathrm{p}=.80 ; \mathrm{q}=1-.80=.20 ; \mathrm{z}^{2}=1.96$ at $95 \%$ level of significance; $\mathrm{d}=.05$. Thus, our sample size $\mathrm{N}=(1.96)^{2}(.80)$ $(.20) /(.05)^{2}=246$.

\subsection{BARTLETT'S TEST OF SPHERICITY AND KMO TEST}

According to higher score of Chi-Square which is 398.784 resulting from Bartlett's test of sphericity, the null hypothesis that the variables are uncorrelated in the population is rejected with 78 degrees of freedom, which is significant at the 0.05 level. Again, the larger value of Kaiser-Meyer-Olkin (KMO) statistic $(.737>0.5)$ indicates that there is correlations among variables to influence the application of HRIS in an organization.

\begin{tabular}{lrr}
\hline \multicolumn{3}{c}{ KMO and Bartlett's Test } \\
\hline Kaiser-Meyer-Olkin Measure of Sampling Adequacy. & .737 \\
Bartlett's Test of Sphericity & Approx. Chi-Square & 398.784 \\
& df & 78 \\
& Sig. & .000 \\
\hline
\end{tabular}

\subsection{RELIABILITY AND VALIDITY TEST}

This study is designed to unearth the fact that how management perceives about HRIS initiation \&adoption in terms of organizational performances in three perspectives such as operational efficiency, managerial effectiveness and strategic finesse. Based on sifted literature and empirical study, a questionnaire was designed to reflect the construct. Then the internal consistency reliability was measured by Cronbach's Alpha, which is 0.74 , that is high enough for researches in social sciences (Kalayci, 2005). This score meets requirement. 


\begin{tabular}{rrr}
\multicolumn{3}{c}{ Reliability Statistics } \\
Cronbach's Alpha & Cronbach's Alpha Based on Standardized Items & N of Items \\
.740 & .741 & 14 \\
\hline
\end{tabular}

\subsection{DATA ANALYSIS}

The top management perceptual dimensions about HRIS performance were showed by a five-point Likert scale. The scale was pointed as " 1 - strongly disagree" and " 5 - strongly agree". Then data were fed into SPSS software to run the tests. At first, Kolmogorov-Smironv test was conducted to test whether data are normally distributed and the results showed that data were distributed normally and parametric tests are possible to run.

\subsection{DESCRIPTIVE STATISTICS}

Top level people from different industry have participated in this study. The following table shows the demographic information about the respondents. It shows that $96 \%$ respondents are male and only $4 \%$ are female. It means that top level is male-dominated. In educational qualification, $78 \%$ of top level management hold master level certificate. However, experienced HR is at the helm of organization, which is vivid from experience taxonomy.

\begin{tabular}{|c|c|c|}
\hline \multicolumn{3}{|c|}{ Table: Demographic information about the participants } \\
\hline Name & Category & $\%$ \\
\hline \multirow[b]{2}{*}{ Gender } & Male & 96 \\
\hline & Female & 4 \\
\hline \multirow{5}{*}{ Education } & MBA & 40 \\
\hline & M. Com & 38 \\
\hline & Graduation & 14 \\
\hline & Degree & 3 \\
\hline & Others & 5 \\
\hline \multirow{5}{*}{ Experience } & $<5$ & 8 \\
\hline & 6-10 years & 25 \\
\hline & $11-15$ years & 32 \\
\hline & $16-20$ years & 20 \\
\hline & 21-above & 15 \\
\hline \multirow{5}{*}{ Position } & Director (active) & 23 \\
\hline & Chairman (active) & 2 \\
\hline & CEO & 6 \\
\hline & Manager & 54 \\
\hline & Others & 15 \\
\hline
\end{tabular}

The following table shows that there $51 \%$ responding organizations are manufacturing type and the rest $49 \%$ are service type. This indicates the optimal distribution of sample to portrait real picture economy wide. A majority of companies (86\%) are Bangladesh origin though only $14 \%$ are foreign multinational companies.

\begin{tabular}{llr}
\hline Name & Category & $\%$ \\
\hline \multirow{2}{*}{ Business Nature } & Manufacturing & 51 \\
& Services & 49 \\
Company origin & Bangladeshi & 86 \\
& Foreign & 14 \\
\hline
\end{tabular}

There are 13 questions in the questionnaire focusing on three dimensions of organizational performance. They are operational efficiency, managerial effectiveness and strategic finesse. The following table shows the percentage of "agree and strongly agree" and "disagree and strongly disagree" against each perceptual dimension. 


\begin{tabular}{llrrr} 
Q. N. & Operational Efficiency & Agree & Disagree & Neutral \\
\hline 3 & HRIS produces standardized information & 78 & 14 & 8 \\
4 & HRIS entails complexity rather than simplicity. & 19 & 65 & 16 \\
5 & HRIS erodes privacy of the organization. & 29 & 61 & 10 \\
8 & HRIS is a time consuming system. & 28 & 54 & 18 \\
9 & HRIS increases cost rather than benefits of the organization & 10 & 77 & 13 \\
& Total & 164 & 271 & 65 \\
& Mean & $33 \%$ & $54 \%$ & $\mathbf{1 3} \%$
\end{tabular}

The table shows that $54 \%$ respondents view HRIS as a tool to enhance operational efficiency. On the other hand, $33 \%$ respond that HRIS blocks efficiency by increasing complexity, time, cost and crippling privacy in the organization.

\begin{tabular}{llrrr}
\hline Q.N. & Managerial Effectiveness & Agree & Disagree & Neutral \\
\hline 1 & HRIS hinders the process of decentralization & 14 & 74 & 12 \\
2 & HRIS bars quick decision making. & 28 & 60 & 12 \\
6 & HRIS diminishes managerial capability & 16 & 73 & 11 \\
7 & HRIS requires higher capability of employees. & 44 & 37 & 19 \\
10 & HRIS confronts higher resistance from the employees & 27 & 43 & 30 \\
& Total & 129 & 287 & 84 \\
& Mean & $\mathbf{2 6 \%}$ & $\mathbf{5 7 \%}$ & $\mathbf{1 7 \%}$ \\
\hline
\end{tabular}

The set of questions upon "managerial effectiveness by HRIS" indicates that $57 \%$ respondents agree with the statement "HRIS enhances managerial effectiveness" while $26 \%$ respondents disagree with the same statement. Out of all, $17 \%$ remain neutral.

\begin{tabular}{llrrr}
\hline Q.N. & Strategic Finesse & Agree & Disagree & Neutral \\
\hline 11 & HRIS plays a minor role in strategic HR tasks. & 19 & 67 & 12 \\
12 & HRIS is an de-enabling technology & 8 & 68 & 24 \\
13 & HRIS impacts organizational performance negatively & 14 & 76 & 10 \\
& Total & 41 & 211 & 46 \\
& Mean & $14 \%$ & $\mathbf{7 0 \%}$ & $\mathbf{1 6 \%}$ \\
\hline
\end{tabular}

The third set of questions was about strategic finesse contributed by HRIS. Out of responses, $70 \%$ said that HRIS positively influence in formulating and executing strategy. On the other hand, $14 \%$ opined negative influence of HRIS upon strategic process. And, $16 \%$ remained neutral.

\subsection{DISCUSSION AND HYPOTHESIS TESTING}

In this section we discuss the result of our hypothesis tests.

H1: Management perceptions about HRIS outcome show difference according to gender.

\begin{tabular}{|c|c|c|c|}
\hline \multicolumn{4}{|c|}{ Chi-Square Tests } \\
\hline & Value & $\mathrm{df}$ & Asymp. Sig. (2-sided) \\
\hline Pearson Chi-Square & $4.979^{a}$ & 4 & .289 \\
\hline Likelihood Ratio & 6.038 & 4 & .196 \\
\hline $\mathrm{N}$ of Valid Cases & 201 & & \\
\hline
\end{tabular}

a. 5 cells $(50.0 \%)$ have expected count less than 5 . The minimum expected count is .32 .

The null hypothesis developed for the test, that is, effective use of HRIS is independent of gender and as Asymp. Sig. (2-sided) is .289, which is higher than 0.05, and therefore the null hypothesis is not subject to rejection. As such it can be concluded that the variables are not associated significantly with each other. In other words, the result indicates that gender has no impact on HRIS perception of top management. H2: Management perceptions about HRIS outcome show difference according to experience. 


\begin{tabular}{|c|c|c|c|}
\hline \multicolumn{4}{|c|}{ Chi-Square Tests } \\
\hline & Value & df & Asymp. Sig. (2-sided) \\
\hline Pearson Chi-Square & $21.559^{a}$ & 16 & .158 \\
\hline Likelihood Ratio & 24.607 & 16 & .077 \\
\hline Linear-by-Linear Association & 1.734 & 1 & .188 \\
\hline $\mathrm{N}$ of Valid Cases & 201 & & \\
\hline
\end{tabular}

In order to establish whether there is a significant association between the working experience in decision making position and perception of top management towards HRIS performance, the Chi Square Test for Independence was performed. The result shows that the Asymp. Sig. (2-sided) is .158, which is higher than 0.05 . Therefore, the null hypothesis is not subject to rejection. As such, it can be concluded that the two variables are not associated significantly with each other.

H3: Management perceptions about HRIS outcome show difference according to educational level.

\begin{tabular}{lrrr} 
& Chi-Square Tests & & \\
& Value & df & Asymp. Sig. (2-sided) \\
\hline Pearson Chi-Square & $17.926^{\text {a }}$ & 16 & $\cdot 328$ \\
Likelihood Ratio & 21.220 & 16 & .170 \\
N of Valid Cases & 201 & &
\end{tabular}

a. 15 cells (60.0\%) have expected count less than 5. The minimum expected count is 20 .

In order to establish the association between level of education and top management perception toward HRIS performance, the Chi Square Test was run. The null hypothesis formulated is that there is no association between level of education and management perception. The Asymp. Sig (2-sided) test value 0.328 , which is less than 0.05 . Therefore, the null hypothesis is subject to non-rejection. It can be concluded that level of education (contemporary academic knowledge) is not significantly associated with top management perception toward HRIS performance.

H4: Management perceptions about HRIS outcome show difference according to company origin.

$\begin{array}{lrrr} & \text { Chi-Square Tests } & & \\ & \text { Value } & \text { df } & \text { Asymp. Sig. (2-sided) } \\ \text { Pearson Chi-Square } & 24.210^{\mathrm{a}} & 12 & .019 \\ \text { Likelihood Ratio } & 17.004 & 12 & .149 \\ \text { N of Valid Cases } & 201 & & \end{array}$

a. 13 cells $(65.0 \%)$ have expected count less than 5 . The minimum expected count is .04 .

The null hypothesis developed to test association company origin and top management perception toward HRIS performance. According to Pearson Chi-Square, that is 0.019 (Asymp. Sig. (2-sided), which is less than .05, the null hypothesis is rejected. It means that there is significant association between company origin and managerial perception toward HRIS performance.

\subsection{FINDINGS \& CONCLUSION}

Managing people for sustainable competitive advantage is the prime goal of Human Resource Management in the $21^{\text {st }}$ century. HRIS has evolved as a successful HR tool to ensure proper utilization of HR to advance the interest of the organization. In this study, the outcome of HRIS was described under three perspectives such as Operational Efficiency, Managerial Effectiveness and Strategic Finesse. A firm can avail the boon of HRIS in those areas with the commitment, decisions and actions of management. Thus, management support is the key to HRIS formulation and execution in a firm. 
We also find a number of interesting results. First, more than half of the respondents (54\%) said that HRIS benefits organization by producing customized information at right time to right people in right form, which are cost-efficient and duly encrypted. All these contribute to enhance operational efficiency in the organization. Second, HRIS also ease management and ensure managerial effectiveness. 57\% respondents responded that HRIS reduces bureaucratic intrigue, smoothes decision making process, solidifies managerial capability and communicates employee better. Thus, HRIS accelerates managerial effectiveness. Third, HRIS plays inevitable role in strategic management process. According to findings, $70 \%$ of respondents are of view that HRIS is an enabling system, which helps in underscoring HR as core competency. Fourth, results of the tested hypothesis show that perception of management toward HRIS initiation, adoption and outcomes are not associated with gender, managerial experiences but significantly associated with whether the company is foreign or Bangladesh origin. Finally, we show that level of education is not associated with management perception toward HRIS though $40 \%$ and $38 \%$ respondents hold MBA and M.Com respectively. There could be two possible causes of it. Either education has little impact in practical application or proper knowledge is not imparted regarding contemporary tools in the classes.

\section{REFERENCES}

Armstrong, M. (2008). Strategic Human Resource Management: A Guide to Action, Kogan Page, London.

Ball, K.S. (2000), The use of human resource management system: a survey, Personnel Review, 30 (6), 2000, 677-693.

Bal, Y., Bozkurt, S., Ertemsir, E. (2012), The Importance of Using Human Resources Information System (HRIS) and A Research on Determining the Success of HRIS, Management, Knowledge and Learning; International Conference 2012, Page: 08\& 53-62

Beckers, A. M. and Bsat, M. Z. (2002), "A DSS classification model for research in human resource information systems", Information Systems Management, Vol. 19 No. 3, pp. 41-50.

Beadles, N. A., Lowery, C. M., \& Johns, K. (2005). The impact of human resource information systems: An exploratory study in the public sector, Communication of the IIMA, 5(4), pp. 39-46.

Beadles-II, N. A., Lowery, C. M. \& Johns, K. (2005). The Impact of Human Resource Information Systems: An Exploratory Study in the Public Sector. Journal of Communications of the IIMA, 5(4), 39-46.

Bondarouk et al (2009) found three key determinant of the effective use of HRIS such as organizational factors, personal factors and cultural factors.

Bondarouk, T., Ruel, H., Guiderdoni-Jourdain, K., \& Oiry, E. (2009), Handbook of Research on ETransformation and Human Resources Management Technologies: Organizational Outcomes and Challenges, IGI Global Press.

Bozkurt, Ertemsir \& et al (2012) showed that both HRIS perception and HRIS satisfaction of employees result from position variable, not from age, educational level or seniority in the management.

Johnson, J et al. (2001), Collaborating on project success, http://www.softwaremag.com/L, cfm? Doc=archive/2001feb/CollaboratingMgt.html, retrieved on 12 October, 2013.

Kalayci, A. (2005). Evaluation of apical sealing ability and adaptation to dentine of two resin-based sealers. Journal of oral rehabilitation, 32(2), 105-110.

Kenneth A. Kovach, Allen A. Hughes, Paul Fagan and Patrick G. Maggitti (2002), "Administrative and Strategic Advantages of HRIS", Employment Relations Today, Vol. 29 Issue: 2, pages 43-48.

Kovach, K. A., \& Cathcart, C. E. (1999). Human resource information systems (HRIS): Providing business with rapid data access, information exchange and strategic advantage. Public Personnel Management, 28(2), 275-282.

Kovach, K. A., \& Cathcart, C. E. (1999). Human resource information systems (HRIS): Providing business with rapid data access, information exchange and strategic advantage. Public Personnel Management, 28(2), 275-282.

Laudon, K., \& Laudon, J. (2009). Management Information Systems: International Edition, 11/E. Pearson Higher Education. 
Lawler, E. \& Mohrman, S.A. (January 2003), HR as a strategic partner: what does it take to make it happen? Marshall School of Business, Centre for Effective Organization, University of Southern California: CEO Publication.

Lengnick-Hall, M. L. \& Moritz, S. (2003). The impact of e-HR on the Human Resource Management Function. Journal of Labor Research, 24(3), 365-379.

Mayfield, J., Mayfield, M., \& Lunce, S. (2003). Human Resource Information Systems: A Review and ModelDevelopment. Advances in Competitiveness Research. 11(1), 139-151.

Overman, S. (1992). Reaching for the 21st Century. HR Magazine, 37, 61-63.

Roda, C \& Nabeth, T. (2008), Attention management in organization: Four levels of support in information systems, In A Bounfour, Organizational Capital: Modeling, Measuring and Contextualizing. Routledge (Advanced research series in management). Routledge. Pp. 214-233

Siriwardene A. S. \& Dharmasiri A. S. (2010) FactorsImpeding Effective Use of Human Resource Information Systems (HRIS) in Local Banks in Sri Lanka, pp. 20-22

Shaikh S. (2012), "Human resource information system (HRIS) designing needs for business application", ZENITH International Journal of Business Economics \& Management Research, Vol.2 Issue 1, January, pp 256-264.

Stone, R \& Davis, J. M. (2009), Change Management: Implementation, Integration and Maintenance of the HRIS, In M. Thite and M.J. Kavanagh (Eds), Human Resource Information Systems: Basics, Applications and Future Directions, California: SAGE Publications Inc. pp 173-208.

Shiri, S. (2012). Effectiveness of Human Resource Information System on HR Functions of the Organization - A Cross Sectional Study. US-China Education Review, A (9), 830-839.

Tannenbaum, S.I. (1990). Human Resource information Systems: User Group Implications. Journal of Systems Management. 41(1), 27-32.

Teo, T. S. H., Soon, L. G. \& Fedric, S. A. (2001). Adoption and impact of Human Resource Information Systems (HRIS). Research and Practice in Human Resource Management, 9(1), 101-117.

Troshani, I., Jerram, C., \& Rao Hill, S. (2011). Exploring the public sector adoption of HRIS. Industrial Management \& Data Systems, 111(3), 470-488.Kinnie N.J. \& Arthurs A. J. (1996), Personnel specialists' advanced use of information technology: evidence and explanations, Personnel Review, 25 (3), 3-19

Wei, S. \& Feng, A. (2013). Research on applications of Human Resource Information System in SMEs. 2nd International Conference on Science and Social Research (ICSSR) 2013. Atlantis Press, 804-807.

Yeung, A. \& Brockbank, W. (1995), Reengineering HR through information technology, Human Resource Planning, Vol. 18 No. 2, 24-37 